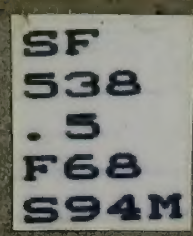




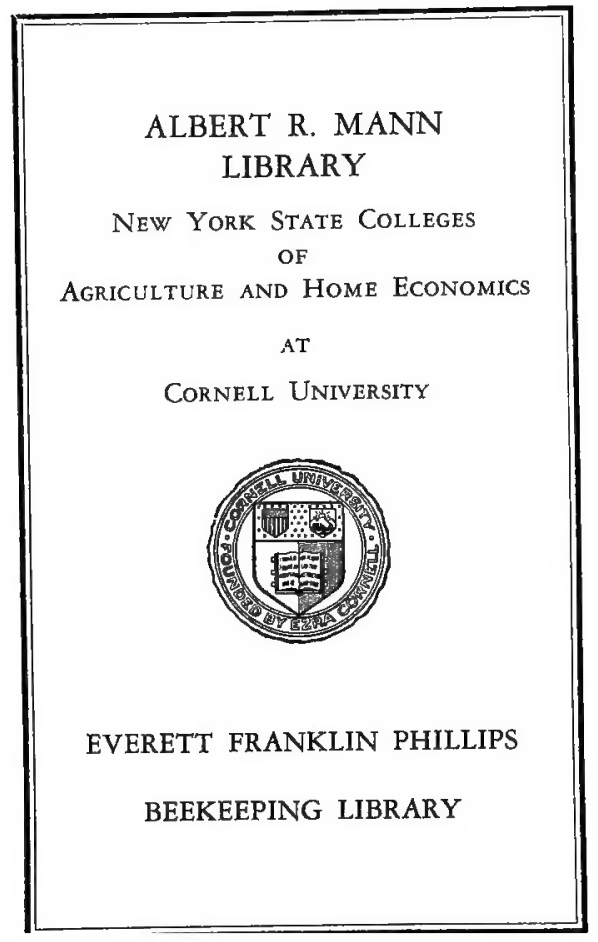




\section{MIXED INFECTION IN THE BROOD DISEASES OF BEES}

By Arnold P. Sturtevant, Specialist in the Bacteriology of Bee Diseases, Bureau of Entomology, United States Department of Agriculture

The two principal brood diseases of bees, European foulbrood and American foulbrood, heretofore have not been found associated together commonly in the same colony. The generally accepted belief has been that it is indeed a rare occurrence to find both diseases under these conditions. Sacbrood, on the other hand, is much more often found in greater or less quantity associated with either European foulbrood or American foulbrood, but seldom assuming dangerous proportions, either alone or in conjunction with the others. Statistics for the past few years, however, show that these cases of what may be called mixed infection are probably more common than was previously supposed and may account for some of the puzzling instances where colonies have not responded to treatment in the customary manner, thereby causing beekeepers to believe they have some new form of brood disease, or that the disease is showing some new unheard of characteristics.

Cases of so-called mixed infections are not at all uncommon among human diseases. Where this condition occurs, such as when a person affected with typhoid fever develops pneumonia at the same time, it is always the individual to whom the term mixed infection is applied. It is a somewhat different matter in the case of the brood diseases of bees. In the first place, so far as is known, the organisms causing these two diseases, Bacillus larvae of American foulbrood and Bacillus pluton of European foulbrood, have never been found together in the same individual larva. It is, therefore, the colony as whole which is to 
be considered as the individual unit, as is the case in the majority of the manipulations of beekeeping practice. This fact makes the problem slightly different from a case of mixed infection as considered from the point of view of human medicine. However, since different individuals are involved in the mixed infections there is no "a priori" reason for considering such cases as impossible.

The first published report of an authentic instance where both American and European foulbrood were found together in the same comb from a diseased colony was reported by McCray. ${ }^{1}$ This report was concerning a sample (4982) received at the laboratory for diagnosis May 4, 1916, from Stanislaus County, California. Previous to this case only one other such sample (2598 from Brown County, Wisconsin in 1911) had been received for diagnosis, showing the presence of both diseases, but no report concerning it was published. These two samples were the only known authentic cases on record either in the Bee-Culture Laboratory among practically 5000 samples received up to 1916 , or in the beekeeping literature. These two cases were considered to be interesting in that they demonstrated that the presence of both diseases at the same time in a colony was possible, but not much importance was given the matter because of their rare occurrence. White ${ }^{2}$ states that "such a double infection has been encountered in the writer's experience very rarely. In such diagnoses, therefore, after European foulbrood had been found in the sample, American foulbrood is seldom looked for." This practice has been the custom generally as well when American foulbrood was found present in a sample, no further search for European foulbrood being made unless there were present strikingly prominent symptoms abnormal for American foulbrood. As a result the diagnostic records of the Office of Bee-Culture show but six cases of mixed infection up to December 31, 1918, among the approximately 6000 sample records.

Developments during the year 1919, however, showed that mixed or double infection is more probable than had been previously supposed. These facts were particularly impressed upon the writer during the spring of 1919 while on a trip investigating the bee disease conditions in the State of California. While in the field during a period of less than one month, and in three different counties of the State of California, six cases were found showing both American foulbrood and European foulbrood in the same colonies. Each case was diagnosed posivitely at once in the field by means of microscopic examination of dead larvae showing characteristic symptoms of the two diseases and found to contain the specific causative organisms. It is interesting to note that three

${ }^{1}$ McCray, A. H. 1916. Report of the finding of American Foulbrood and European foulbrood in the same comb. Jour. of Eco. ENT. Vol. IX, p. 379.

${ }^{2}$ White, G. F., 1920. European foulbrood. U. S. Dept. of Agric. Bul. 810. 
of the six samples were found in Stanislaus County in the same locality as the sample reported by McCray in 1916 . These cases were all found in regions where both diseases are exceedingly prevalent and of long standing. A few of the samples were fairly self evident from gross appearances, but the majority required a more minute examination.

From that time on, particularly after, returning to the laboratory in Washington, more careful examination was made, both gross and microscopic of all samples received because of suspicions aroused by the unusual prevalence of the obvious cases found in California. This was done in order to eliminate the danger of overlooking cases where one disease might be predominant over the other, whether both diseases were suspected or not, causing the less prominent to be overlooked.

As a result, during the remainder of the year 1919 from June until December, twelve more such samples were received in the laboratory from various parts of the country, (18 in all for that year, total 24) all of which proved upon careful diagnosis to contain both American foulbrood and European foulbrood in the same sample of comb. Furthermore, during the year 1920, up until November 15th, fourteen more such samples were received, making a total in all of 38 . Tables 1 and 2 give the data from sample records.

TABle I.-CASES OF MiXed Infection from Laboratory Records

\begin{tabular}{|c|c|c|c|c|c|}
\hline Date & Lab. No. & State & County & $\begin{array}{l}\text { Apparent primar } \\
\text { invader from gros } \\
\text { appearance }\end{array}$ & Remarks \\
\hline $9-20-11$ & 2598 & Wisconsin & Brown & ? & Diagnosed by G. F. White \\
\hline $5-4-16$ & 4982 & California & Stanislaus & American $\mathrm{fb}$. & Diagnosed by A. H. McCray \\
\hline $6-3-16$ & 5061 & California & Stanislaus & American fb. & Diagnosed by A. H. McCray \\
\hline $\begin{array}{l}5-16-17 \\
5-9-18\end{array}$ & 5392 & Missouri & $\begin{array}{l}\text { Jasper } \\
\text { Washington }\end{array}$ & Probably Afb. & Apoarently about equa \\
\hline $\begin{array}{r}5-9-18 \\
10-9-18\end{array}$ & $\begin{array}{l}5836 \\
6122\end{array}$ & $\begin{array}{l}\text { Mississipp1 } \\
\text { Wisconsin }\end{array}$ & $\begin{array}{l}\text { Washington } \\
\text { Barron }\end{array}$ & $?$ & $\begin{array}{l}\text { Apparently about equa } \\
\text { More Efb than Afb }\end{array}$ \\
\hline $4-19-19$ & 6437 & California & Santa Barbara & Probably Efb. & One cell Afb. \\
\hline $4-26-19$ & 6441 & California & Sacramento & American fb. & From history of case \\
\hline $\begin{array}{l}4-26-19 \\
4-28-19\end{array}$ & $\begin{array}{l}6442 \\
6445\end{array}$ & $\begin{array}{l}\text { California } \\
\text { California }\end{array}$ & $\begin{array}{l}\text { Sacramento } \\
\text { Stanislaus }\end{array}$ & American fb. & Few cells Afb. \\
\hline $4-30-19$ & 6449 & California & Stanislaus & American fb. & $\begin{array}{l}\text { Few cells Afb. } \\
\text { Few cells Efb. }\end{array}$ \\
\hline $5-1-19$ & 6452 & California & Stanislaus & European $\mathrm{fb}$. & From history of case \\
\hline $\begin{array}{l}5-20-19 \\
6-11-19\end{array}$ & $\begin{array}{l}6304 \\
6401\end{array}$ & $\begin{array}{l}\text { Missouri } \\
\text { Ohio }\end{array}$ & Lewis & $?$ & \\
\hline $6-27-19$ & $\begin{array}{l}0401 \\
6498\end{array}$ & Iowa & Johnson & American fb. & Efb early stages, also Sacbrood \\
\hline $8-1-19$ & 6629 & Ohio & Trumbull & $?$ & \\
\hline $8-15-19$ & 6672 & Connecticut & Tolland & Probably Efb. & Afb slight amount \\
\hline $\begin{array}{l}8-25-19 \\
8-29-19\end{array}$ & $\begin{array}{l}6698 \\
6716\end{array}$ & $\begin{array}{l}\text { Kansas } \\
\text { New York }\end{array}$ & $\begin{array}{l}\text { Cherokee } \\
\text { Cayuga }\end{array}$ & $\stackrel{?}{\text { American } \mathrm{fb} .}$ & Efb active Afb scales \\
\hline $9-2-19$ & 6721 & Washington & Pacific & ? & LID active RilD searies \\
\hline $9-2-19$ & 6722 & Washington & Pacific & $?$ & Efb more prominent \\
\hline $9-19-19$ & 6768 & California & Santa Barbara & $?$ & Afb 1st disease reported for county \\
\hline $\begin{array}{r}9-26-19 \\
10-5-19\end{array}$ & 6778 & California & Santa Barbara & $?$ & \\
\hline $\begin{array}{r}10-5-19 \\
5-12-20\end{array}$ & $\begin{array}{l}0834 \\
6985\end{array}$ & $\begin{array}{l}\text { California } \\
\text { California }\end{array}$ & Santa Cruz & $\stackrel{?}{?}$ & Afh $\mathrm{ft}$ \\
\hline $5-29-20$ & $\begin{array}{l}0900 \\
7023\end{array}$ & Michigan & $\begin{array}{l}\text { Butte } \\
\text { Calhoun }\end{array}$ & $\begin{array}{c}\text { European tb. } \\
\text { ? }\end{array}$ & Arb one or two cells \\
\hline $5-29-20$ & 7025 & Michigan & Calhoun & $?$ & \\
\hline $5-29-20$ & 7026 & Wisconsin & Fond du Lac & European fb. & Few celis Afb \\
\hline $\begin{array}{l}6-17-20 \\
6-17-20\end{array}$ & $\begin{array}{l}7119 \\
7120\end{array}$ & $\begin{array}{l}\text { Washington } \\
\text { Washington }\end{array}$ & $\begin{array}{l}\text { Lew1s } \\
\text { Lewis }\end{array}$ & $\xi$ & Also Sacbrood \\
\hline $6-22-20$ & 7143 & New York & Allegany & European fb. & Few cells Afb. \\
\hline $\begin{array}{l}6-24-20 \\
6-26-20\end{array}$ & 7158 & Pennsylvania & $\begin{array}{l}\text { Crawford } \\
\text { Cayuga }\end{array}$ & $?$ & \\
\hline $6-26-20$ & 7174 & New York & Cayuga & $?$ & \\
\hline $6-26-20$ & 7177 & Pennsylvania & Crawford & $?$ & \\
\hline & 7335 & New Ỹork & Seneca & Probably Afb. & \\
\hline${ }_{0}^{\circ}$ & & iana & Blackford & & \\
\hline-20 & 7387 & Indiana & Blackford & $\lambda$ & \\
\hline
\end{tabular}


Table II.-Samples of Mixed Infection by Years

\begin{tabular}{|c|c|c|}
\hline Year & $\begin{array}{l}\text { Samples of } \\
\text { mixed infection }\end{array}$ & $\begin{array}{c}\text { Total Samples } \\
\text { received }\end{array}$ \\
\hline 1911 & $\mathbf{1}$ & 1042 \\
\hline $1916 \ldots \ldots \ldots \ldots \ldots \ldots \ldots \ldots \ldots \ldots \ldots$ & 2 & 374 \\
\hline $1917, \ldots{ }^{2}$ & 1 & 449 \\
\hline 1918 & 2 & 429 \\
\hline $1919 \ldots \ldots \ldots \ldots \ldots \ldots \ldots \ldots \ldots \ldots \ldots \ldots \ldots \ldots$ & 18 & 693. \\
\hline $1920 \ldots \ldots \ldots \ldots \ldots \ldots \ldots \ldots \ldots \ldots \ldots \ldots$ & 14 & 698 \\
\hline-1920 & $\overline{38}$ & $\overline{7568}$ \\
\hline
\end{tabular}

This marked apparent increase in cases of mixed infection carries the subject over from one of scientific interest to one of practical importance. As is shown in Table III, the 38 samples of mixed infection have come from 24 counties in thirteen states, most of these located in prominent beekeeping regions. In eleven of these thirteen states both European foulbrood and American foulbrood as shown by samples of disease received in the laboratory for diagnosis are prevalent and of long standing. There are only about three or four other states where both diseases have been found in quantity from which samples of mixed infection have not been received, while only from two states of the many where the diseases are only occasionally bad have such samples been received.

\section{Table III.-SAmples of Mixed Infection by States and Counties}

\begin{tabular}{|c|c|c|}
\hline State & Counties & Samples \\
\hline California. & 5 & 12 \\
\hline Connecticut $\ldots \ldots \ldots \ldots \ldots \ldots \ldots \ldots \ldots \ldots \ldots \ldots$ & 1 & 1 \\
\hline 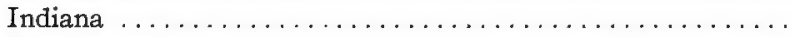 & 1 & 2 \\
\hline 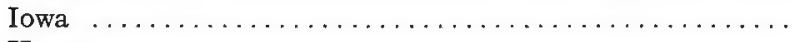 & 1 & 1 \\
\hline 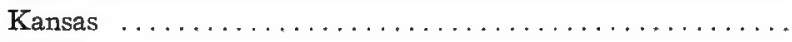 & 1 & 1 \\
\hline Michigan $\ldots \ldots \ldots \ldots \ldots \ldots \ldots \ldots \ldots \ldots \ldots$ & 1 & 2 \\
\hline Mississippi $\ldots \ldots \ldots \ldots \ldots \ldots \ldots \ldots \ldots \ldots \ldots$ & 1 & 1 \\
\hline 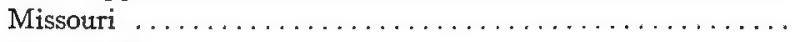 & 2 & 2 \\
\hline 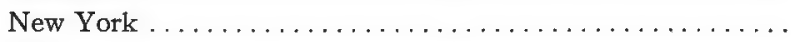 & 3 & 5 \\
\hline 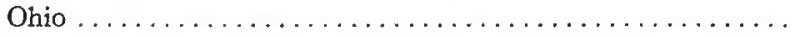 & 2 & 2 \\
\hline$\ldots \ldots \ldots \ldots \ldots \ldots \ldots \ldots \ldots \ldots$ & 1 & 2 \\
\hline 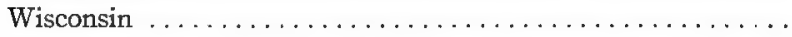 & 2 & 3 \\
\hline 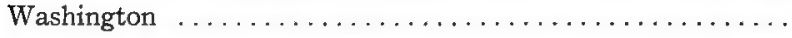 & 2 & 4 \\
\hline
\end{tabular}

Statistics obtained from the sample records, however, are not entirely conclusive since a majority of the samples come to the laboratory unsolicited. If a careful survey could be made of the regions where the brood diseases are bad and widespread, probably many more such cases would come to light. 
Table IV.-Distribution of Samples of Mixed Infection by Months

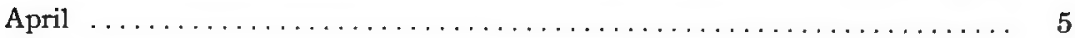

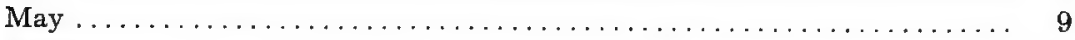

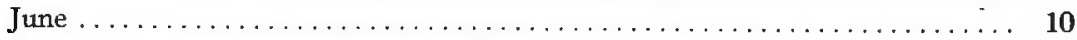

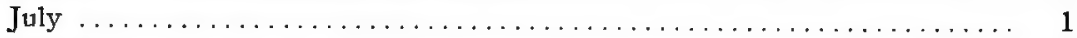

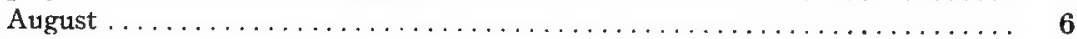

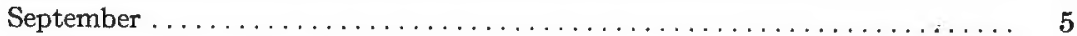

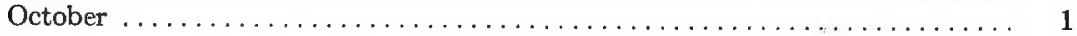

November ......................................... 1

These samples of mixed infection have been examined in eight out of the twelve months of the year, April to November inclusive, as shown in Table IV. Twenty-four of the total 38 samples, nearly 65 per cent., were examined during the months of April, May and June, the months during which European foulbrood is most prevalent. ${ }^{3}$ In contrast to the spring months, eleven samples of mixed infection were examined during August and September, and only one each in July, October and November, a total of fourteen.

The question, however, of which diesase is most often the primary invader in a colony is difficult to answer, particularly without a history of the colony and locality. (Table I). If only dried adhesive American foulbrood scales are found, accompanied by numerous coiled fresh moist melting larvae of European foulbrood, it is not difficult to say that American foulbrood was the primary invader, perhaps during the previous season, as was the case of the sample reported by McCray. But often there is no such demarkation. Because the presence of American foulbrood depletes the strength of the colony this increases the probability of European foulbrood infection.

Since the requirements of the treatment of the two diseases are so entirely different, the necessity for correct diagnosis becomes of importance, particularly in regions where both diseases have been prevalent for some time. The presence of both diseases in the same colonies or even in the same apiary is a complicating factor in the diagnosis and treatment. Furthermore there is danger from the possibility of continued and confusing losses due to the ignorance of the presence of mixed infection in colonies under such circumstances and resulting therefrom, improper treatment which would only continue the losses.

Several samples have been received for diagnosis which beekeepers have thought contained both diseases and which indeed seemed to have some of the characteristics of each. Upon careful examination, however, both gross and microscopic, these have mostly proven to be definitely not mixed infections. The recognition of cases of mixed infection in

\footnotetext{
${ }^{3}$ Phillips, E. F., 1918. The control of European foulbrood. U. S. Dept. of Agric.
} Farmers' Bulletin 975, 16 pp. 
colonies is often difficult because of the fact, as is particularly the case with European foulbrood, there are many irregularities and variations in symptoms that often add to the confusion of the beekeeper in making gross diagnosis hurriedly in the field. In order to more easily differentiate some of these confusing symptoms to assist in gross diagnosis, they may be divided into three classes. Occasionally in an unusually virulent case of American foulbrood or in one where the bees have deserted the brood because of its foul condition allowing what healthy brood there is to starve, larvae will be found which have died while still coiled in the cell, among the typical American foulbrood larvae. ${ }^{4}$ These coiled larvae often have much the same appearance as typical European foulbrood coiled larvae. However, the consistency is generally quite different from European foulbrood, more like the typical slimy glue-like consistency of American foulbrood material. As a rule, however, the symptoms of American foulbrood are uniformly constant because of the fact that Bacillus larvae is almost always the only invader of the larvae causing death and a type of decomposition which prevents growth of other organisms. Several such cases were found in California.

A second class of confusing symptoms are found in samples which come particularly from regions where European foulbrood has been allowed to run unchecked for a long time. Such samples were found in certain sections of California and have been received from various other sections of the country. These samples show along with more or less of the typically coiled European foulbrood larvae, large numbers of larvae which have died after extending and even being sealed in the cell, showing a consistency somewhat like that of American foulbrood but more lumpy or like an old partly rotten rubber band. ${ }^{5}$ Sometimes scales are found extended in the cells in such large numbers as to appear on casual examination like an old comb of American foulbrood. Close examination, however, shows the consistency, irregular shape and position with lack of adherence to the cell wall to be different from that in American foulbrood. This type was found to be quite prevalent in California.

The third class is composed of cases of actual mixed infection where typical American foulbrood, ropy larvae or scales, are associated in the same comb with typical European foulbrood, coiled moist melting larvae, or possibly occasionally the abnormal rubbery irregular larvae mentioned above. The active stage of the two diseases often seems to be localized more or less in different parts of the comb. This is probably due to

\footnotetext{
${ }^{4}$ White, G. F. 1920. American foulbrood. U. S. Dept. of Agric. Bul. No. 809.

${ }^{5}$ Sturtevant, A. P., 1920. A study of the behavior of colonies affected by European foulbrood of bees. U. S. Dept. of Agric. Bul. No. 804.
} 
the fact that the queen would tend to desert that section of the comb containing the American foulbrood, particularly where this disease was the primary invader. In many cases one or the other of the diseases will be more prominent, at least in the active stages. This fact may be one of the causes for cases of mixed infection having been overlooked, the beekeeper seeing only the prominent outstanding symptoms. Therefore in cases where there is doubt or suspicion that both diseases may be present in the same colony, a positive laboratory diagnosis often appears to be desirable.

As is well known, the shaking method of treatment in its essentials is so far the only successful way of treating American foulbrood. ${ }^{6}$ The nature of Bacillus larvae has prevented success along any other line, because of its ability to form exceedingly resistant spores and especially to decompose the dead larva in such a way as to cause the mass containing large numbers of these spores to adhere to the cell wall as if glued. It has been learned furthermore, often by sad experience, that the shaking treatment is practically never successful in the treatment of European foulbrood; in fact, often when used causes the disease to be spread all the more because of the weakening effect the shaking has on the colonies. ${ }^{7}$ The requirements for the successful treatment of European foulbrood have been found to be fundamentally dependent upon adequately strengthening the colonies with young bees sufficiently to throw off the disease, ${ }^{7}$ at the same time combined with the requeening of the diseased colonies with vigorous young Italian queens, permitting the bees themselves to remove the infected material.

The apparent logical solution of the problem of the treatment for a known case of mixed infection, therefore, is to combine the treatments for both American foulbrood and European foulbrood as a single treatment. In other words, the one or more colonies known or strongly suspected to have mixed infection should be shaken as for American foulbrood, requeening them with vigorous young Italian queens and later strengthening them by the addition of young bees or hatching brood from a healthy colony, or by uniting later. Strength of colony is the important factor combined with the shaking and requeening with vigorous Italian stock.

The problem of the control of mixed infections of American foulbrood and European foulbrood is primarily associated with the control of European foulbrood. In localities where both diseases are prevalent

\footnotetext{
${ }^{6}$ Phillips, E. F. 1920. The control of American foulbrood. U. S. Dept. of Agric., Farmers' Bulletin No. 1084.

${ }^{7}$ Phillips, E. F. 1918. The control of European foulbrood. U. S. Dept. of Agric., Farmers' Bulletin No. 975 .
} 
and there is suspicion of both being present in the same apiary, and possibly even some as mixed infection in the same colony, control of the two diseases will depend upon the elimination of European foulbrood first. This should be done by treating the entire apiary for European foulbrood, by strengthening and requeening all the colonies with young and vigorous Italian queens, which is after all only good beekeeping. After the elimination of European foulbrood it will be a simple matter to determine those colonies that have not responded to this treatment, as being American foulbrood. This method is possible because of the fact that American foulbrood seldom spreads with the rapidity of European foulbrood, particularly if care is taken to prevent robbing and mixing up of combs. Those colonies which continue to show American foulbrood remaining may now be given the usual shaking treatment. 
Cornell University Library

Mixed infection in the brood diseases of

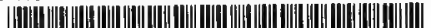

31924003262080

mann 
